\title{
電気湿度計による防湿加工紙の透湿度測定についで
}

\author{
高 橋 文 男・内 藤 泰 俊**
}

\section{An Electric Hygrometer Method of Test for Water \\ Vapor Transmission Rate of Coated Paper}

Fumio Takahashi and Yasutoshi Naito

\begin{abstract}
A new method for measurement of WVT is reported here. Akker's comparison method which is based orr the use of electric hygrometer was improved. The following were the objectives:

1. Device must be appropriate to measurements of the WVT of different kinds of coated paper.

2. Faster measurement than JIS method should be made.

3. The electric hygrometer which is response to the higher humidity range $(60-90 \%$ R.H.) should be used.

We measured the WVT of polyethylene coated krafts using improved comparison method, and decided such test conditions as the results of our method accord with the results of JIS method for example, number of tests, standardization of resistor of permeation, acceptable accuracy of electric hygrometer, etc.
\end{abstract}

\section{1. 研究の目的}

現在防湿材料の透湿度测定方法としては重量法が最 も一般的に利用され，JIS の試験法規格 (Z 0208)にも 採用されている。この方法の欠点は測定完了までに 70 時間程度の長時間を必要とすることで，そのためこの 方法を防湿材料の製造中の品質管理あるいは受渡し検 查に利用する場合には種々な不都合を生じている。ま た测定法自体においても，透湿カップの組立てあるい は科量の繰りかえしなど簡便とは言い難いお法である。

電気湿度計を利用した透湿度測定法は，特に測定時 間の短縮を日的として考えられた方法で, 1948 年には J. A. Van den Akker ${ }^{1}$ が, Dynamic 法, Comparison 法, Sweep-gas 法の 3 種類の方法について説明を行な い, その後もこの湘定法についての研究2) 3) が重ねら れてきた。

それらの䂙究のほとえどは Dynamic 法によるもの で, この法は数分〜数十分で測定が完了する最も迅 速な测定法であるが，

1）定常状態での測定ではない。

2）湿度: $0 \%$ 近くの低湿度に拈いては正確な測定が できる電気湿度計を必要とし，このような湿度計 は製作ならびに補正が非常に困難である。

3）プラスチックス加工紙のよらにその一面あるい は両面に紙セロハンなどの吸湿性の大きい材料を 持つものについては，その紙・セロハンなどを低

* 原稿受付 40.1 .26

** 産業工芸試駼所

昭和 40 年 5 月
湿度側とした場合の测定が不可能である。 などの欠点がある。また Comparison 法では透湿係数 に湿度依存性 ${ }^{4}$ のある材料は測定できない, Sweep-gas 法では低湿度範囲の測定が可能な電気湿度計 2 個を必 要とするなどの欠点がある。

この研究ではプラスチックス加工紙などの防湿加工 紙に対しても適用できる方法として，しかも

1）重量法では测定条件に打いて湿気の透過が定常 状態に達した後に測定が開始されるのであるが， その定常状態に達した時に执いて測定を完了させ るよらにする。

2) 電気湿度計は湿度の测定範囲が $60 \sim 90 \%$ 程度 のものを使用する。

3）透湿係数に湿度依存性の山る材料にも適用でき るようにする。

4）JIS Z 0208 の重量法によって測定した透湿度と 一致する透湿度を求める。

ことを目的とし，Comparison 法の改良法による測定 法を見出した。そしてこの測定法による透湿度と JIS 法による透湿度の比較検討を行なった結果，この測定 法を品質管理などにおける測定法として実施する場合 に必要な各種条件を求めた。

\section{2. 測 定 原理}

Comparison 法の测定原理は図 1ー1に示すような 装置を使用し，透湿の標準抵抗々試験片との間の空間 の湿度が一定になった時の湿度すなわち平衡湿度を電 気湿度計により测定する。この平衡湿度 h は, 図 $1-2$ 
1. 蓄 置 $90 \%$ R. H.

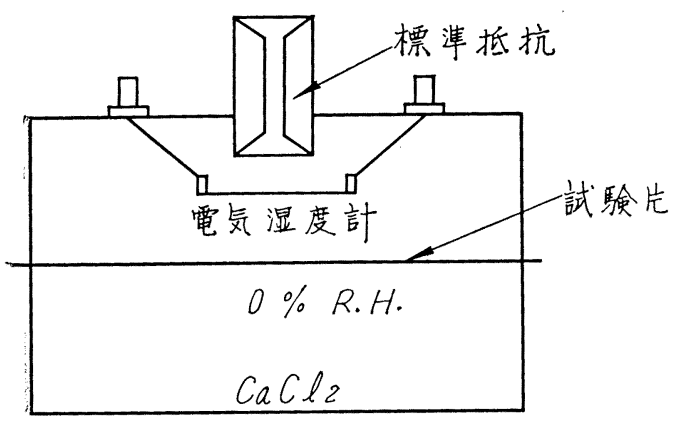

2. 計 算 図

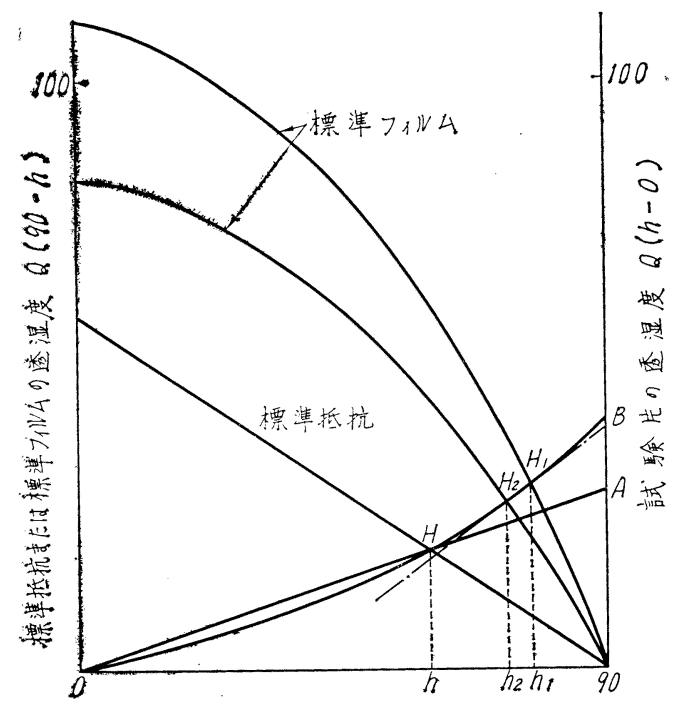

標渠抵抗と試鈋尼火の间の空間の乎衡湿度

図 1 Comparision 法の測定原理

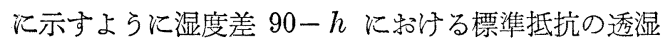
度と湿度差 $h-0$ 飞扔ける試験片の透湿度が等しくな るような位㯰をとる5)。その結果図 1 -2 亿执いて平 行比例の関係から

試験片の透湿度=標準抵抗の透湿度 $\times \frac{90-h}{h-0} \cdots$ (1) によって計算される。

しかし一般の防湿材料に执いては湿度差と透湿度と の関係は図 1-2 の $\mathrm{O}-\mathrm{H}-\mathrm{A}$ 亿示されるような直線で はなく，O-H-B に示されるようないわゆる透湿係数 飞湿度依存性の市る曲線である場合が多い。それ故(1) 式によって求めた透湿度は JIS 法による透湿度に対し て相当な䛊差を生じる場合が多い。このためこの研究 では，標準抵抗のかわりに適当なプラスチックスフィ ルムを標準フィルムとして使用し, この標準フィルム

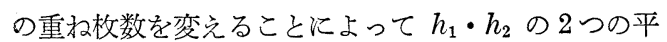
衡湿度を求め, 標準抵抗を使用した場合の $H$ 飞相当
する点を $2 つ\left(H_{1} \cdot H_{2}\right)$ 求めて，さらにこの 2 点を結 ぶ直線と $90 \%$ に打ける透湿度を示す軸との交点を求め て，これを試験片の透湿度とする方法をとった。（図 $1-2$ 参照)

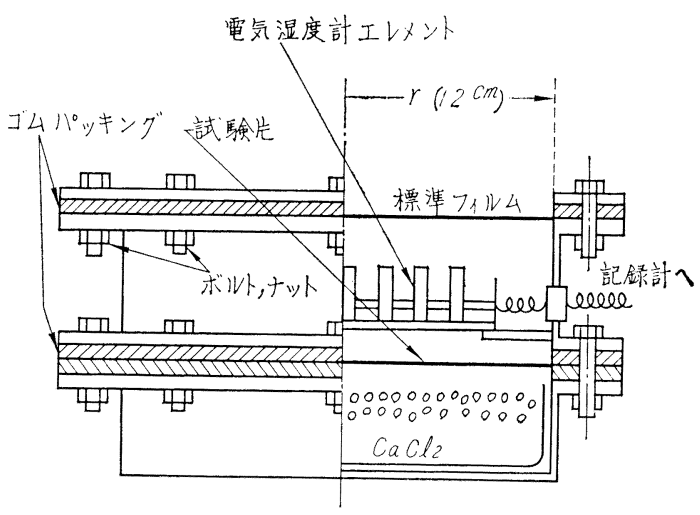

図 2 測 定 装置

\section{3. 実験および結果}

3.1 測定装置 測定装置は図 2 亿示すものを使

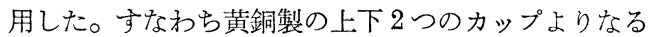
もので，下部カップには無水塩化カルシゥムを入れて その上試験片を置く, さらにその上に頂部に標準〉 イルムを取り付け内部に電気湿度計を組み込んだ上部 カップを置き，ボルト・ナットで結合密封して装置と する。電気湿度計は山武八ネウエル計器 K.K. の塩化 リチウム感湿エレメント（湘定範囲 $35 ９ 5 \%$ R.H.) を電子管式自記記録計に接続したものを使用した。こ の湿度計の補正は一般室温条件中に新いて乾湿球湿度 計と比較して行なった。

この装置を温度 $40^{\circ} \mathrm{C}$ 湿度 $90 \%$ に保った恒温恒湿室 中に，標準フィルム之試験片との間の空間の湿度が一 定になるまですなわち平衡湿度がでさるまで放置して 測定を行なった。

3.2 標準フィルム 標準フィルムには公称厚さ $0.03 \mathrm{~mm}$ の軟質ポリ塩化ビニール・フィルムを使用し た。この塩化ビニールフィルム 1 枚あるいは $2,3,4$ 枚 と重沿合せた場合のそれぞれの透湿度を，JIS Z 0208 の透湿カップを使用した重量法により測定した。

ただし透湿カップの内部には表 1 亿示すような各種 試薬を入れて内部湿度をそれぞれに変化させた。この 透湿カップに塩化ビニールフィルムの各重称枚数をと りつけ， $40^{\circ} \mathrm{C}, 90 \%$ R.H. の測定条件中で透湿度を測 定した。この透湿度を標準フィルムの $Q(90-h)$ と して各重社枚数ごとに表 1 亿示す。表 1 の結果から， 標準フィルムの各重亦枚数について, 外部湿度を $90 \%$ 
表 1 標準フィルムの透湿度 $Q(90-h) \quad\left(\mathrm{g} / \mathrm{m}^{2} \cdot 24 \mathrm{hr}\right)$

\begin{tabular}{|l|c|c|c|r|r|}
\hline カップにスれた試薬 & 湿度 $h \%$ 重枚数 $n$ & 1 & 2 & 3 & 4 \\
\hline $\mathrm{CaCl}_{2}$ & 0 & 98.4 & 49.2 & 32.8 & 24.6 \\
$\mathrm{MgCl}_{2} \cdot 6 \mathrm{H}_{2} \mathrm{O}$ & 32 & 67.6 & 33.8 & 22.5 & 16.9 \\
$\left(\mathrm{NH}_{2}\right)_{2} \mathrm{CO}$ & 67.5 & 26.2 & 13.4 & 9.0 & 6.5 \\
$\mathrm{NaCl}$ & 75 & 17.4 & 8.6 & 5.8 & 4.2 \\
$\left(\mathrm{NH}_{4}\right)_{2} \mathrm{SO}_{4}$ & 79 & 11.8 & 5.7 & 3.8 & 2.8 \\
\hline
\end{tabular}

として内部湿度を変化させた場合の透湿度 $Q(90-h)$ の変化を図 3 に示すように求めた。

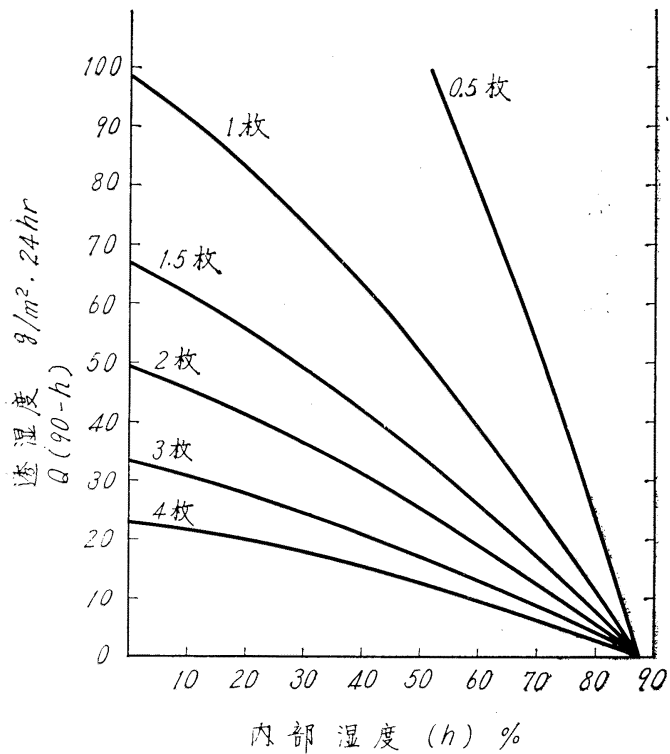

図 3 標準フィルム (ポリ塩化ビニール $0.03 \mathrm{~mm}$ )の 透湿度と内部湿度との関係 (外部湿度 $90 \%$, at $40^{\circ} \mathrm{C}$ )

表 1 ではゴジックで組んだ透湿度が実測值で，その 他の透湿度は，透湿度は重水枚数に反比例する6) もの として計算により求めた。また図 2 の装置に沶いて試 験片の表面積を標準フィルムの表面積の $1 / 2$ にること により，標準フィルムの重敉枚数 0.5 枚および 1.5 枚 を仮定することができる。この重㸚枚数の透湿度も同 様にして計算して図 3 に示す。
3.3 測定および結果＼cjkstart測定試料には，ポリエチ レンの加工厚さ公称 $0.02 \mathrm{~mm}$ のポリエチレン加工クラ フト紙を使用した。試料から試験片 4 枚を取り，各試 験片をその表面積が標準フィルムの表面積の $1 / 2$ となる ようにして，クラフト紙面を低湿度側に向けて図 2 の 装置にそれぞれ取り付けた。さらに標準フィルムを取 り付けた装置を $40^{\circ} \mathrm{C}, 90 \%$ R.H. に保った恒温恒湿室 中に，標準フィルムと試験片との間の空間の湿度が一 定となるまで放置した。この平衡湿度はこの測定の場 合には $16 〜 20$ 時間後に得られた。

各試験片に対して標準フィルム 1，2，3，4 枚を使 用してそれぞれの枚数を使用した場合の平衡湿度 $h_{n}$ を求めたが，これは標準フィルムと試験片の表面積比 が $2: 1$ であるので，標準フィルムを0.5，1，1.5， 2 枚を使用した場合の平衡湿度となる。この平衡湿度を 図 3 に対照して，標準フィルムの $90-h_{n}$ の湿度差に 特ける透湿度 $Q\left(90-h_{n}\right)$ を求めた。測定原理で述べ たよらにこの標準フィルムの $Q\left(90-h_{n}\right)$ は試験片の $h_{n}-0$ の湿度差に护る透湿度 $Q\left(h_{n}-0\right)$ に等しい, このようにして求めた $h_{n}$ と $Q\left(h_{n}-0\right)$ を表 2 に示 于े

表 2 の $h_{n}$ と $Q\left(h_{n}-0\right)$ とを座標として1 試験片 につい $H_{0.5}, H_{1}, H_{1.5}, H_{2}$ の 4 点を図上にプロット して図 4 の 1 ～に示し，この 4 点の中の各 2 点の組 合せによってできる 6 本の直線から， $h_{n}=90$ の場合 の透湿度すなわち試験片の 90 - $0 \%$ の湿度差に和ける 透湿度 6 個を図 4 上に求めた結果を表 3 に示す。すた 表 3 には以上の測定に使用した各試験片の透湿度を JIS Z 0208 の測定法によって测定した結果を示す。

表 2 ポリエチレン加工クラフト紙について測定された $h_{n}(\%)$ と $Q\left(h_{n}-0\right)\left(\mathrm{g} / \mathrm{m}^{2} \cdot 24 \mathrm{hr}\right)$

\begin{tabular}{|c|c|c|c|c|c|c|c|c|c|}
\hline \multirow{2}{*}{\multicolumn{2}{|c|}{$\begin{array}{r}\text { 栖潐フイルムの } \\
\text { 重ね杴数 } \\
\text { 試験片 No. }\end{array}$}} & \multicolumn{2}{|r|}{0.5} & \multicolumn{2}{|r|}{1} & \multicolumn{2}{|r|}{1.5} & \multicolumn{2}{|r|}{2} \\
\hline & & $h_{n}$ & $Q\left(h_{n}-0\right)$ & $h_{n}$ & $Q\left(h_{n}-0\right)$ & $h_{n}$ & $Q\left(h_{n}-0\right)$ & $h_{n}$ & $Q\left(h_{n}-0\right)$ \\
\hline & & 78 & 25 & 71 & 22.1 & 65.5 & 19.4 & 60.5 & 17.9 \\
\hline & & 76 & 30.5 & 66.5 & 28.1 & 58 & 25.7 & 53.5 & 22.0 \\
\hline & & 78 & 25 & 69.5 & 24.1 & 63 & 21.6 & 57.5 & 19.6 \\
\hline & & 77 & 27.8 & 69.5 & 24.1 & 63.5 & 21.1 & 58 & 19.3 \\
\hline 平 & 均 & 77.2 & 27.6 & 69 & 24.8 & 62.5 & 22.0 & 57.4 & 19.7 \\
\hline
\end{tabular}




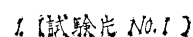

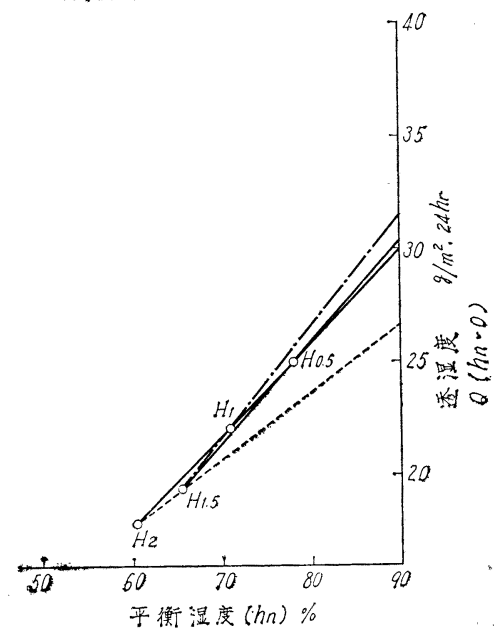

3. (試駼说 No.3)

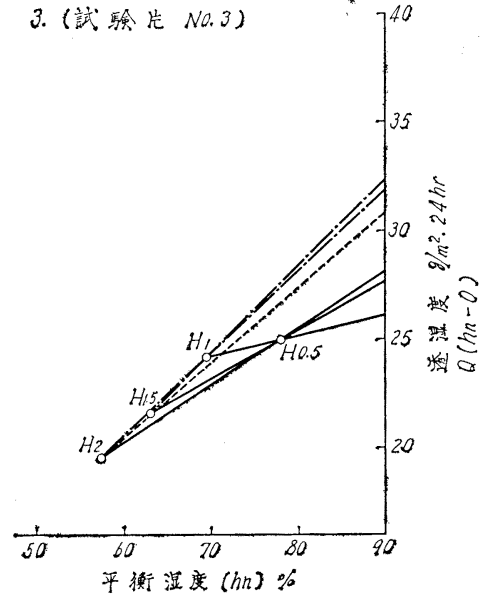

2. (試験光 No.2)
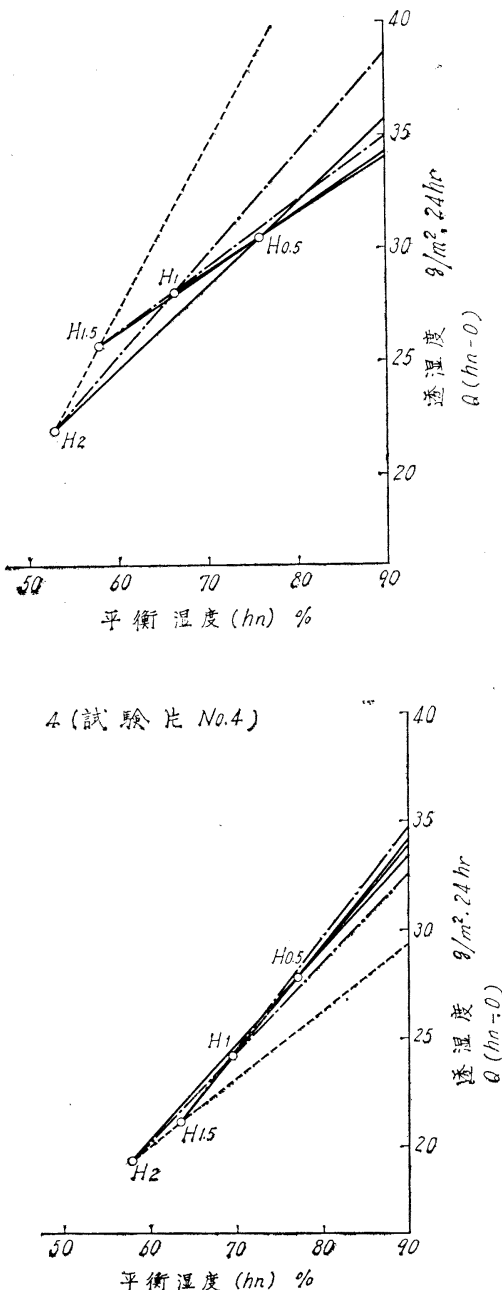

図 4 ポリエチレン加工クラフト紙の透湿度の計算図表

表 3 ポリエチレン加工クラフト紙の各試験片についての透湿度測定結果

\begin{tabular}{|c|c|c|c|c|c|c|c|c|}
\hline 試 験 片 No. & \multicolumn{4}{|c|}{1} & \multicolumn{4}{|c|}{2} \\
\hline JIS 法による実測值 & \multicolumn{4}{|c|}{$30.8 \mathrm{~g} / \mathrm{m}^{2} \cdot 24 \mathrm{hr}$} & \multicolumn{4}{|c|}{$34.5 \mathrm{~g} / \mathrm{m}^{2} \cdot 24 \mathrm{hr}$} \\
\hline \multirow{4}{*}{ 図 4 に抢ける計算值 } & & $H_{0.5}$ & $H_{1}$ & $H_{1.5}$ & & $H_{0.5}$ & $H_{1}$ & $H_{1.5}$ \\
\hline & $H_{1}$ & 29.9 & & & $H_{1}$ & 34.0 & & \\
\hline & $H_{1.5}$ & 30.5 & 31.6 & & $H_{1.5}$ & 34.3 & 34.9 & \\
\hline & $H_{2}$ & 29.9 & 29.9 & 26.8 & $H_{2}$ & 35.7 & 38.8 & - \\
\hline 試 験 片 No. & \multicolumn{4}{|c|}{3} & \multicolumn{4}{|c|}{4} \\
\hline JIS法による実測值 & \multicolumn{4}{|c|}{$31.7 \mathrm{~g} / \mathrm{m}^{2} \cdot 24 \mathrm{hr}$} & \multicolumn{4}{|c|}{$33.6 \mathrm{~g} / \mathrm{m}^{2} \cdot 24 \mathrm{hr}$} \\
\hline \multirow{4}{*}{ 図 4 に批子る計算值 } & & $H_{0.5}$ & $H_{1}$ & $H_{1.5}$ & & $H_{0.5}$ & $H_{1}$ & $H_{1.5}$ \\
\hline & $H_{1}$ & 26.1 & & & $H_{1}$ & 33.9 & & \\
\hline & $H_{1.5}$ & 27.7 & 32.4 & & $H_{1.5}$ & 34.4 & 35.1 & \\
\hline & $\mathrm{H}_{2}$ & 28.2 & 32.0 & 31.2 & $H_{2}$ & 33.5 & 32.8 & 30.0 \\
\hline
\end{tabular}


さらに図 5 には，表 2 の 4 枚の試験片についての標 準フィルムの各枚数ごとの $h_{n}$ の平均値と, この平均 值から図 3 によって求めた $Q\left(h_{n}-0\right)$ の平均值とを座 標としてプロットし，図 4 と同様にして透湿度を求め

表 4 ポリエチレン加工クラフト紙の

4 測定の平均值から求めた透湿度

\begin{tabular}{|c|llll|}
\hline JIS 法による & \multicolumn{4}{|c|}{$32.7 \mathrm{~g} / \mathrm{m}^{2} \cdot 24 \mathrm{hr}$} \\
\hline 実測値の平均
\end{tabular}
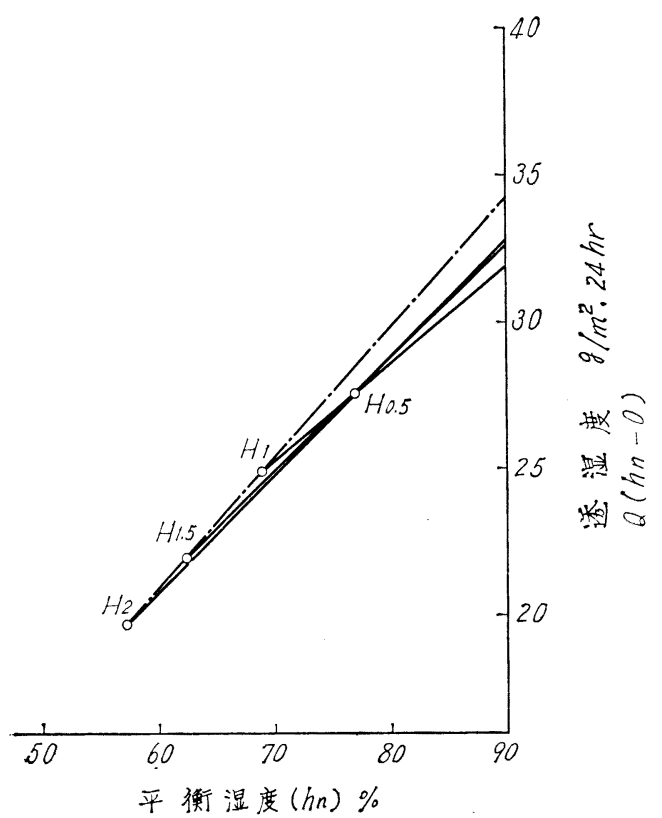

図 5 ポリエチレン加工クラフト紙の透湿度の 計算図表 4 测定（図4 1 4) の平均
て 4 試験片の透湿度の平均値とし，これを 4 試験片の JIS 法による透湿度の平均值と対照して表 4 に示す。 つぎに，以上の結果にもとづいて，次節以下に述べ るような結論を求め，この結論にしたがって，たとえ ば標準フィルムの標準化などを行なった上で，ポリエ チレンサンドイッチクラフト紙 2 種類 (A.B) につい て透湿度測定を行なった結果をつぎに示す。

試料から試験片 6 枚を取り，このらちの 3 枚につい ては試験片 1 枚に対して標準フィルム 1 枚を使用し， 他の 3 枚についてはその 1 枚に対して標準フィルムを 4 枚重ねたものを使用して装置に取り付け測定を行な った。標準フィルムと試験片の面積比は $1: 1$ とした。 その結果を表 5 および図 6 に示す。

\section{$J / S$ 法によ子实测值計算値

$\begin{array}{lll}A & 13.6 & 13.5 \\ B & 11.5 & 10.9\end{array}$

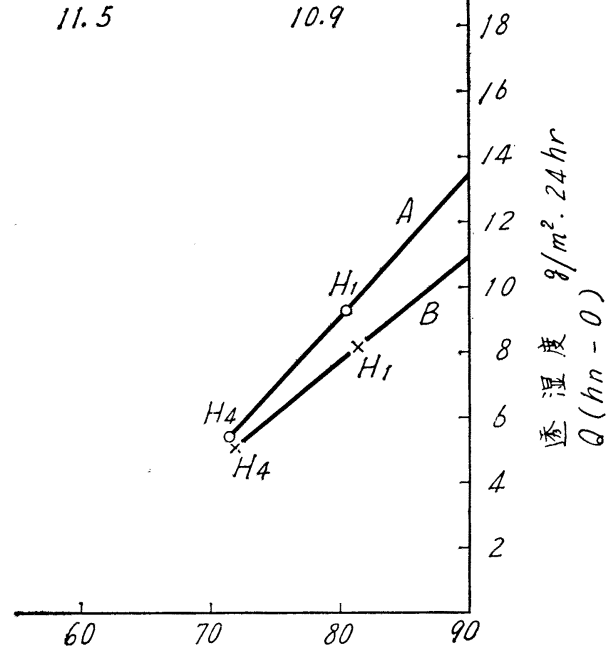

平衡湿度 $\left(h_{n}\right) \%$

図 6 ポリエチレンサンドイッチクラフト紙の 透湿度の計算図表

表 5 ポリエチレン・サンドイッチクラフト紙についての測定結果

\begin{tabular}{|c|c|c|c|c|c|c|}
\hline \multirow[b]{2}{*}{ 標測フィルムの枚数 } & \multicolumn{2}{|c|}{ 試料の種類 } & \multicolumn{2}{|r|}{ A } & \multicolumn{2}{|r|}{ B } \\
\hline & & & $h_{n} \%$ & $Q\left(h_{n}-0\right) \mathrm{g} / \mathrm{m}^{2} \cdot 24 \mathrm{hr}$ & $h_{n} \%$ & $Q\left(h_{n}-0\right) \mathrm{g} / \mathrm{m}^{2} \cdot 24 \mathrm{hr}$ \\
\hline \multirow{4}{*}{1} & & & 79.5 & & 81 & \\
\hline & & & 81.5 & & 80.5 & \\
\hline & & & 81 & & 82.5 & \\
\hline & & 均 & 80.7 & 9.3 & 81.3 & 8.1 \\
\hline \multirow{4}{*}{4} & & & 69.5 & & 71.0 & \\
\hline & & & 72.5 & & 71.5 & \\
\hline & & & 72.5 & & 73 & \\
\hline & & 均 & 71.5 & 5.4 & 71.8 & 5.1 \\
\hline
\end{tabular}




\section{4. 考察}

1）図 4 に和いてプロットされた 4 つの点は，同一 の試験片に対して使用する標準フィルムの重效枚数を 変えることによって得られた点であるから，この 4 点 はその試験片についての図 1-2の OHB に相当する 透湿度の曲線 $Q(h-0)$ 上にのっていなければなら ない。しかもこのことは，この測定法による透湿度を 正確に求めるために必要なことである。しかし図 4 の 1〜4にプロットされた各点は, 各試験片についての $Q(h-0)$ の曲線から多少づれているものがあると認 められる。これは主として実際の測定に使用した標準 フィルムの透湿度 $Q(90-h)$ が図 3 に示した曲線に 対して偏差があったためと考えられる。このため各点

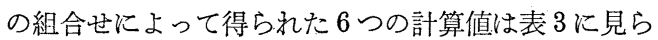
れるようなばらつきを示し，JIS 法による実測值に対 してはなはだしくはなれた值もある。

2） 2 節に述べた測定原理から言えば， $Q(90-0)$ を求めるためて図上にプロットする 2 点は, 湿度 $90 \%$ のごく近くで求めしかもたがいに接近していることが の㐫しい。一方標準フィルムの透湿度のばらつきに よりまえに述べたような誤差を生じ，乙かも図 3 に示 されるよらに湿度 $90 \%$ に近いほど標準フィルムの $Q$ $(90-h)$ の曲線の勾配が急であることから考えると， ある程度低湿度でしかもたがいにはなれた位置に 2 点 を求めた方が䛊差が少なくなる。図4 に打いても標準 フィルムの唀湿度のばらつきが大きかるたために生じ たと思われる点, たと壳ば 4-2 の $H_{2}, 4-3$ の $H_{0.5}$ があるが，これらの点に対してもよりはなれた位置に ある点と結んだ直線から求めた透湿度の方が，その試 験片についての透湿度の実測值に比較的近くなってい る。(表 3 )

3）表3に拈いて一般的に言えることは， $H_{0.5}$ の 点に対して $H_{1.5}$ あるいは $H_{2}$ の点を結んだ直線から 求めた透湿度が最も実測值に近似している。なたこの 4 测定にはまえに述べたようなばらつきを含んでいる のであるが，その平均值として求めた㘠 5 拉よび表 4 に計算された透湿度はいずれも実測值に近くなってい る。特に表 4 では $H_{0.5}-H_{1.5}, H_{0.5}-H_{2}$ の組合せか ら求めた透湿度は実測值に医とんど一致している。

4) ポリエチレン加工クラフト紙はその透湿係数に 多少の湿度依存性を持っている7) が，この方法によれ ば測定が可能である。しかし一般的により湿度依存性 の大きい材料ター永リン紙・塩化ビニリデン加工紙防 湿セロハンなどでは，2点をこの測定の場合より $90 \%$ に近い位置に求めた方がよいと考えられる。

\section{5. 総括}

以上の結果からつぎのような電気湿度計による透湿 度测定を実施するための条件を求めた。

1）透湿度を計算するために図上にプロットする 2 点は，それぞれ少なくとも 3 湘定の平均值として求め る必要がある。たとえば標準フィルム1枚を使用した 測定を $3 ， 4$ 枚重ねて使用した測定を 3 ，計 6 測定を 同時に行なら必要がある。試料の透湿度にばらつきが 大きい場合にはより多くの測定が必要となる。

2）以上のような測定を行なう場合には，各測定に 使用する標準フィルムの標準化を行なら必要がある。 すなわちある特定の試験片に対して测定される平衡湿 度が 0.5\% R.H. 以内に一致するような標準フィルム をそろえることが必要である。

3）各測定に使用する各湿度計も同一大気条件中で 使用した場合，湿度の測定值が汇とんど一致するよう に補正することが必要である。

4). 図上にプロットする 2 点を求めるための平衡湿 度 $h_{n}$ は， 1 つは $75 \sim 85 \%$ R.H. の範囲内，他の 1 つ

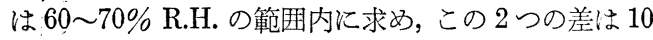
〜15\% R.H. にするのが適当で，平衡湿度がこのよう に測定される標準フィルムの適当な重ね枚数を選択す る必要がある。

5)，測定時間は 20 時間程度を必要とする。

以上の条件にしたがって，ポリエチレン・サンドイ ッチクラフト紙の透湿度を測定した結果は，図 6 に示 すように JIS 法による透湿度とよく一致している。

\section{参考文 献}

1) J. A. Van den Akker: Paper Trade Journal Vol. 126, No. 1, 32 (1948)

2) M. Karel, Y. Aikawa and B. E. Proctor: Modern Packaging Vol. 28, 213 (1955)

3) Hubert O. Ranger and Michael J. Gluckman: Modern Packaging Vol. 37, 153 (July 1964)

4）高橋：産業工芸試験所報告「工芸研究」No. 19, 6 。

5) C. E. Rogers, V. Stannett and M. Szwarc Ind. Eng. Chem. Vol. 49, No. 11, 1933 (1957)

6）高橋：産業工芸試験所報告「工芸研究」No. 19, 6。

7）高橋 - 芦原：産業工芸試験所報告「工芸研究」 No. 27,1 . 